\title{
The Sprouting Activity of Oil Flax Seeds after Treatment with a Preparation Made of Bottom Ash and Technical Carbon
}

\author{
Abilzhan Khusainov ${ }^{1 *}$, Leonid Skipin², Gulmira Kyzdarbekova', Razia Khusainova', \\ Anuar Kakabaev ${ }^{1}$ \\ 1 Sh. Ualikhanov Kokshetau State University, Abay Street, 76, Kokshetau, 020000, Kazakhstan \\ 2 Federal State Budget Educational Institution of Higher Education «Industrial University of Tyumen», \\ Volodarsky St., 38, Tyumen, 625000, Russia \\ * Correspondinfg author's e-mail: abilzhan.khusainov@mail.ru
}

\begin{abstract}
The article provides the results of studying the effect of $0.1,1.0,2.5,5.0,7.5$, and $10 \%$ aqueous suspensions of bottom ash and technical carbon on the germination vigor of the seeds of oil flax and the environmental safety of its use in terms of the content of heavy metals. Laboratory experiments were performed at the environment lab, field experiments - at the experimental field of the Kokshetau State University n.a. S. Ualikhanov. The laboratory germination vigor of the seeds, the length of seedlings, and the mesocotyl were determined according to the Interstate Standard Agricultural Seeds GOST 12038-844. In the field experiment on studying dosages of introducing the drug, the content of heavy metals was determined by the method of stripping voltammetry. The preparation is a mixture of bottom ash and technical carbon in the ratio of 2:1. It has been found that the use of a $5 \%$ aqueous suspension of the preparations contributes to increasing the laboratory germination to $97.0 \%$ ( $88 \%$ in the reference), the length of the mesocotyl to $80 \mathrm{~mm}$ ( $55 \mathrm{~mm}$ in the reference), the length of roots to $79 \mathrm{~mm}$, and the weight of germinated seeds to 1.6 grams (in the reference, these values were $46 \mathrm{~mm}$ and $0.6 \mathrm{~g}$, respectively). After the introduction of the preparation made of bottom ash and technical carbon at the dosages of 100, 200, 300, 400, and $500 \mathrm{~kg} / \mathrm{ha}$, the content of heavy metals insignificantly increases, compared to the reference, but does not exceed the permissible levels in the soil, in the stalks, and in the grains of oil flax; that is, the introduction of the preparation into the soil at the dosages of $100-500 \mathrm{~kg} / \mathrm{ha}$ is ecologically safe. The experimental data have shown that the maximum effect is ensured by pre-sowing treatment of oil flax seeds with a $5 \%$ solution of aqueous suspension made of bottom ash and technical carbon, where the laboratory germination capacity of the seeds increased by $10.2 \%$.
\end{abstract}

Keywords: oil flax, preparation made of bottom ash and technical carbon, laboratory germination, length of roots and mesocotyl, heavy metals.

\section{INTRODUCTION}

According to the Committee of the Land Management of the Ministry of Agriculture of the Republic of Kazakhstan, the area of agricultural lands in the Republic of Kazakhstan amounts to $105,337.4$ thousand hectares, including 25,340 thousand hectares of arable lands. The availability of large areas of land resources provides the opportunity for the Republic to make a significant contribution to solving the global food problem.
According to the Statistics Committee in 2018, the Republic produced 14 million tons of wheat, 2.7 million tons of oilseeds, and other plant products that satisfy the internal and expert needs of the country. However, in Kazakhstan the productivity of crops, including oilseed crops, has been remaining low and unsteady for several years. Thus, the yield of oil flax seeds on average does not exceed $0.5-0.6 \mathrm{t} / \mathrm{ha}$.

One of the important conditions for forming high yields of oil flax seeds is obtaining vigorous and full-fledged germination, which 
is only possible in the case of sowing certified high-class seeds.

The relevance of studying the considered scientific problem is that in the production conditions, it is not always possible to obtain seeds with high sowing qualities. Therefore, the pre-sowing treatment of the seeds of oilseed crops is an integral part of their cultivation technology. Currently, air-and-heat treatment, seed dressing, and other methods are used. In the territory of the Republic of Kazakhstan, insectofungicides are mainly used for the pre-sowing treatment of seeds, such as Akiba (LLC “Agro Expert Group”, Russia), Lamador (company Bayer AG, Germany), Olympus (Sinteziya Kemi GmbH, Germany), Rakson (Redigo Pro, Bayer Crop Science AG, Germany), Redigo Extra (Bayer Crop Science AG, Germany), Celest Top (Syngenta Crop Protection AG, Switzerland), Thenasol Super (Shanghai, MIO Chemical Co., Ltd., China) [n.d., 2015]. The above preparations are mainly used as a means of seeds protection from pests and diseases.

The suggested preparation is used for activating the growth processes in oil flax seeds. The use of bottom ash, coal dust, and other local wastes for pre-treatment of crop seeds does not find practical use due to the insufficient level of knowledge in the Republic of Kazakhstan.

Pradyumna Kumar Singh, Preeti Tripathi, Sanjay Dwivedi, Surabhi Awasthi, Manju Shri, Debasis Chakrabarty, Rudra Deo Tripathi [2016] note that the use of fly ash (FA) in the agricultural sector is a very common practice due to the presence of mineral elements required for the growth of plants [Asiedu et al., 2011].

Zeba Usmani, Vipin Kumar, Pratishtha Gupta, Gauri Gupta, Rupa Rani, Avantika Chandra [2019] report that by 2035, coal consumption in the AsiaPacific region will increase to approximately $87.2 \%$. Management of the coal combustion residuals (CCRs) generated in the industry is a major bottleneck in overcoming the consequences of using coal. The toxicity of microelements in vermicomposted fly ash (VCF) did not reveal any apparent environmental risks. The authors discovered improved germination of the seeds of tomatoes esculentum, melongena by $82.22 \%$, the efficiency of using fly ash (CCR) in agriculture, especially in developing countries [Usmani et al., 2019].

Surface introduction of coal ash is considered an environmentally friendly variant for improving soil quality. The bioavailable concentrations of metals were very low [Mtisi, and Gwenzi, 2019].
The use of coal fly ash (CFA) has become very common due to its economic advantages. However, these residues may contain toxic components that pose a risk to the environment, therefore Khamphe Phoungthong, Li-Ming Shao, Pin-Jing $\mathrm{He}$, Hua Zhang believe it is necessary to assess their environmental toxicity [Khamphe, 2018].

In the Republic of Kazakhstan, the amount of ash and slag waste (ASW) accumulated by the industrial enterprises and residential sectors by 2016 is about 500 million tons, and by 2030 , their accumulation is expected to reach one billion tons.

\section{Scientific novelty and significance}

In the conditions of the sharply continental climate of the steppe zone of Northern Kazakhstan that features late spring, short summer, and early autumn, it is difficult in practice to obtain seeds with high sowing qualities that meet the standard requirements.

The proposed method of pre-sowing treatment of seeds with a preparation made of bottom ash and technical carbon obtained from local wastes can solve the problem of increasing the laboratory germination of oil flax seeds by $10.2 \%$, i.e., using cheap and readily available preparation, it seems possible to bring poor-condition seeds to the sowing conditions, to decrease the seeding rates by $10 \%$, and to obtain vigorous sprouts, which does not pose environmental risk.

In the article, based on the experimental data, the authors have proven the environmental safety of using industrial wastes (bottom ash and technical carbon) for the pre-sowing seed treatment and for fertilizing ordinary black soils to be used for oil flax.

The principle of action of the preparation lies in the fact that the chemical composition of bottom ash includes the elements required for the life activity of oil flax, which helps activate the growth processes in the seeds, and improve oil flax productivity. With that, it is necessary to experimentally test the ecological safety of using it for seed treatment, and as a fertilizer.

The study was aimed at studying the effect of the preparation made of bottom ash and technical carbon suggested by A. A. Sarsenova [2013] on the physiological parameters of germinating seeds of oil flax, and providing the environmental assessment of its use. The objectives of the study included the following: 
- studying the effect $0.1,1.0,2.5,5.0,7.5$, and $10 \%$ aqueous suspensions of bottom ash and technical carbon on the laboratory germination rate of the seeds, the length of the roots and the mesocotyl, and the weight of germinated seeds; establishing the optimal concentration of this preparation for pre-sowing treatment of oil flax seeds;

- giving an environmental assessment of introducing $100,200,300,400$, and $500 \mathrm{~kg} / \mathrm{ha}$ of the drug on the content of heavy metals in ordinary black soil, the straw and the grains of oil flax;

\section{OBJECTS, CONDITIONS, AND METHODS}

The objects of research were ordinary black soil, the preparation made of bottom ash and technical carbon, and the seeds of Severny recognized variety.

The preparation of bottom ash and technical carbon is a powder composed of low-calcium fly ash of Ekibastuz coals and technical carbon. The chemical composition of the fly ash from the Ekibastuz coalfield is as follows: $\mathrm{SiO}_{2} 62.9 \%, \mathrm{Fe}_{2} \mathrm{O}_{3}$ 6.35\%, $\mathrm{Al}_{2} \mathrm{O}_{3} 26.35 \%, \mathrm{CaO} 1.9 \%, \mathrm{MgO} 0.9 \%$, $\mathrm{SO}_{3} 1.2 \%, \mathrm{Na}_{2} \mathrm{O} 0.23 \%$. The macro- and microelemental composition of the fly ash is represented by the following elements in descending order: $\mathrm{K}>\mathrm{Fe}>\mathrm{Al}>\mathrm{Mg}>\mathrm{Ca}>\mathrm{Mn}>\mathrm{Sr}>\mathrm{Pb}>$ $\mathrm{Co}>\mathrm{Zn}>\mathrm{Cu}>\mathrm{Sn}>\mathrm{As}>\mathrm{Ni}>\mathrm{Cd}>$ Hg. Technical carbon consists of carbon by more than $99 \%$ [Sarsenova, 2013].

The laboratory experiment "The Effect of an aqueous suspension of the preparation made of bottom ash and technical carbon on the physiological indicators of flax seeds germination" was laid with four repetitions according to the following scheme: 1) reference - without the use of an aqueous suspension solution; 2) $0.1 \%$ aqueous suspension solution; 3) $1.0 \%$ aqueous suspension solution; 4) $2.5 \%$ aqueous suspension solution; 5) $5.0 \%$ aqueous suspension solution; 6) $7.5 \%$ aqueous suspension solution; and 7) $10.0 \%$ aqueous suspension solution.

In the study, aqueous solutions of bottom ash and technical carbon were used. The gradient of the aqueous suspension concentration in the experiments included the range from $0.1 \%$ to $10.0 \%$, the tested concentrations of the preparation were $0.1 \%, 1.0 \%, 2.5 \%, 5 \%, 7.5 \%$, and $10.0 \%$; and distilled water was used for reference.
The solubility of the preparation made of bottom ash and technical carbon was $90 \%$, the seeds were treated with the aqueous suspension. The physiological characteristics of oil flax seed germination were studied at various concentrations of the aqueous suspension of the studied preparation.

During the experiment, the laboratory germination vigor of the seeds, the length of seedlings, and the length of the mesocotyl were determined according to the Interstate Standard Agricultural Seeds GOST 12038-84. According to the GOST, the seeds were placed into germinators between layers of moistened filtering paper; the flax seeds were germinated at $20{ }^{\circ} \mathrm{C}$. The germinated seeds were assessed and counted for determining the germination rate after seven days. Normally germinated were considered the seeds with welldeveloped roots and healthy appearance, well-developed and intact mesocotyl with a normal apical bud. The germination vigor of the seeds was calculated in percent [GOST 12038-84 Interstate standard. Seeds of crops. Methods of determination of germination. Official edition as amended IUS No. 12, 2016].

To visualize the presence of the relationship between the quantitative variables, a scatter plot was built. Regression equations were derived; each object in the diagram matches a point, the coordinates of which are equal to the values of the pairs selected for the analysis of the variable.

The field experiment was laid at the Elite Educational Scientific and Production Center of the Kokshetau State University named after S. Ualikhanov. The experimental field was located in the steppe zone of Northern Kazakhstan. The soil cover of the experimental plot was ordinary medium loamy carbonate low-humus black soil. According to the Department of Surveying, Land Monitoring and Laboratory Studies, the arable layer of the soil contained $3.96 \%$ of humus, the soil solution reaction was slightly alkaline $(\mathrm{pH}=7.9)$. The content of easily hydrolyzable nitrogen was $46 \mathrm{mg} / \mathrm{kg}$, and that of mobile phosphorus $-17 \mathrm{mg} / \mathrm{kg}$. The degree of availability of hydrolyzable nitrogen by Tyurin and Kononova was moderate, and that of phosphorus by Machigin [Kauricheva, 1986] was low. The content of the studied heavy metals before planting did not exceed the maximum permissible norms.

The experiment was laid with four repetitions according to the following scheme:

1. reference without the use of fertilizers;

2. $\mathrm{P}_{10}$ (1/10 of the calculated dosage), background. 
3. The specified dosage of the phosphorus fertilizer was introduced in all subsequent variants $(3,4,5,6,7)$ - background.

4. background $+100 \mathrm{~kg} / \mathrm{ha}$ of multicomponent carbon-containing preparation;

5. background $+200 \mathrm{~kg} / \mathrm{ha}$ of multicomponent carbon-containing preparation;

6. background $+300 \mathrm{~kg} / \mathrm{ha}$ of multicomponent carbon-containing preparation;

7. background $+400 \mathrm{~kg} / \mathrm{ha}$ of multicomponent carbon-containing preparation; and

8. background $+500 \mathrm{~kg} / \mathrm{ha}$ of multicomponent carbon-containing preparation; the area of the plot was $125 \mathrm{~m}^{2}(5 \times 25 \mathrm{~m})$; the accounting area was $100 \mathrm{~m}^{2}(4 \times 25 \mathrm{~m})$.

In the field experiment, the early maturing flax variety Severny was used. The vegetation period was $70-75$ days. This variety has a complex of valuable characteristics: it matures evenly; and it is resistant to fusarium blight, lodging, and shattering. It is intended for obtaining high-quality technical oil and short fibers.

Soil samples were taken from the $0-20 \mathrm{~cm}$ soil layer according to GOST 28168-89 before sowing and at the phases of tillering and full ripeness of the flax. The gross content of heavy metals was determined by the method of stripping voltammetry at the laboratory of the branch of the RSE at the REM National Expertise Center of the Public Health Committee of the Ministry of Health of the Republic of Kazakhstan for the Akmola region (GOST 50686-94, GOST 50683-94).

The obtained results were processed using statistical methods; for calculations, the Statistica software was used.

\section{RESULTS}

The results of the laboratory experiments showed that the tested preparation had a stimulating effect on the growth processes in the seeds of oil flax. Thus, laboratory germination of the seeds in the reference was $88.0 \%$, and in the variants with treated seeds $-88.5-97.0 \%$, depending on the concentration of the preparation. Moreover, with increasing the concentration from 0.1 to $5.0 \%$, the germination rate increased from 88.5 to $97.0 \%$. An equation was built for linear regression $\mathrm{y}=1.7844 \mathrm{x}+88.231$, a very close correlation $(r=0.99)$ was obtained; further, with the concentrations of the suspension of 7.5 and $10.0 \%$, the germination rate decreased to 91.5 and $90.0 \%$. The maximum effect was obtained in the variant with $5.0 \%$, where the germination of the seeds increased by $10.2 \%$ (Figure 1).

The length of mesocotyl in the reference variant was $55 \mathrm{~mm}$, and in the variants with treatment $-64-80 \mathrm{~mm}$, depending on the concentration of the preparation, which was higher than in the reference by $16.4-46.2 \%$. Here, with increasing the concentration from 0.1 to $5.0 \%$, the length of mesocotyl also increased from 64 to $80 \mathrm{~mm}$; a linear regression equation $\mathrm{y}=3.894 \mathrm{x}+59.102$ was built, close correlation $(\mathrm{r}=0.82)$ was obtained; further, at the concentrations of 7.5 and $10 \%$, their length decreased to 67 and $62 \mathrm{~mm}$ (Figure 2). Even the minimal addition caused the growth of the hypocotyl. A double-peaked Gaussian curve is observed, which indicates the presence of two factors with different optima.

A similar regularity was observed in the length of roots and the weight of germinated seeds. With increasing the concentration of the suspension

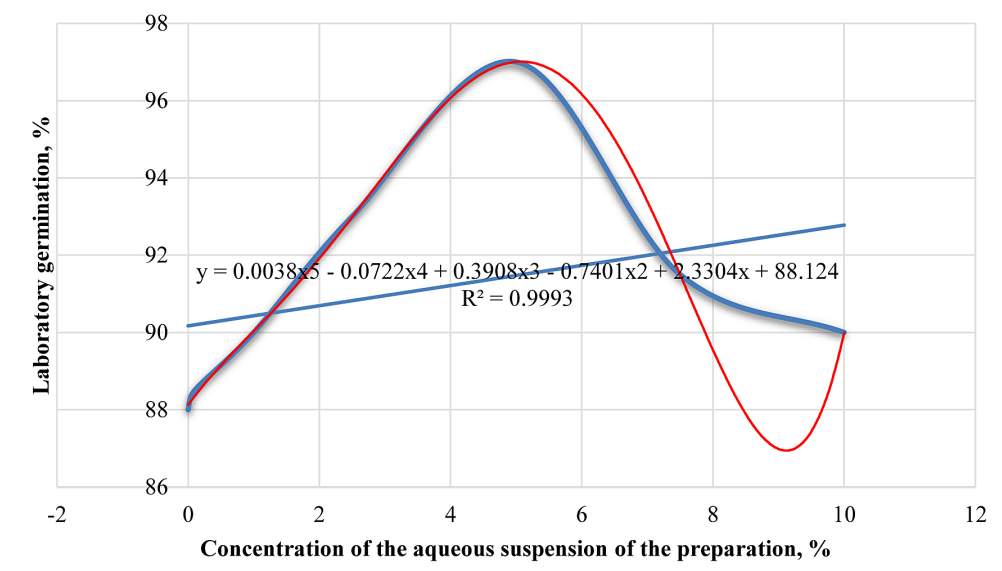

Figure 1. The effect of the multicomponent carbon-containing preparation concentration on the laboratory germination of oil flax seeds 


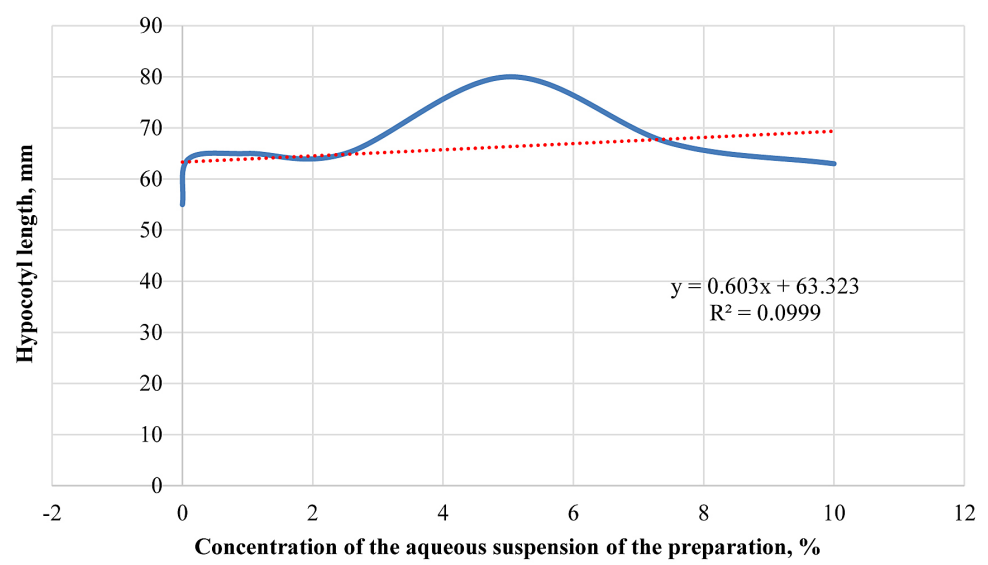

Figure 2. The effect of the multicomponent carbon-containing preparation concentration along the length of the mesocotyl of oil flax

from 0.1 to $5 \%$, the length of the roots increased from 50 to $79 \mathrm{~mm}$ (in the reference $-46 \mathrm{~mm}$ ), and the weight of germinated seeds increased from 0.9 to $1.6 \mathrm{~g}$ (in the reference $-0.6 \mathrm{~g}$ ), the linear regression equations $\mathrm{y}=6.0339 \mathrm{x}+45.622$ and $\mathrm{y}=0.1665 \mathrm{x}+0.8337$ were built, close correlation $(\mathrm{r}=0.85$ and $\mathrm{r}=0.82)$ was also obtained; the increase was from 8.8 to $73.6 \%$ and from 54.3 to $185.8 \%$, respectively. With the concentration of the suspension of 7.5 and $10.0 \%$, these indicators significantly decreased (Figure 3, 4).

Various dosages of the preparation ranging from 100 to $500 \mathrm{~kg} /$ ha on the background of phosphorus fertilizer did not significantly increase the content of heavy metals in the soil, in the stems and the seeds of oil flax.

In the reference variant, the content of lead in the soil was low $-0.52 \mathrm{mg} / \mathrm{kg}$, in the variants with fertilization, its content increased to $1.7 \mathrm{mg} / \mathrm{kg}$; however, this amount was not as high as the allowable norm $-32 \mathrm{mg} / \mathrm{kg}$. The content of lead in the stems of oil flax varied from 0.32 to $0.65 \mathrm{mg} / \mathrm{kg}$ (in the reference $-0.63 \mathrm{mg} / \mathrm{kg}$ ). Lead accumulation in the seeds of oil flax in the variants with fertilization varied from 0.19 to $0.37 \mathrm{mg} / \mathrm{kg}$ (in the reference $-0.26 \mathrm{mg} / \mathrm{kg}$ ) with the norm equal to $1.0 \mathrm{mg} / \mathrm{kg}$. The content of cadmium was only discovered in the soil in variant $1 / 10 \mathrm{R}_{10}$ - background $-0.090 \mathrm{mg} / \mathrm{kg}$. In the stems and the seeds of oil flax plants, no cadmium was detected. The content of zinc in the soil in the variants with fertilization increased from 0.31 to $1.4 \mathrm{mg} / \mathrm{kg}$ (in the reference-0). Copper accumulation in the soil was not observed in all variants with fertilization, but only in the variants with background + preparation $100 \mathrm{~kg} / \mathrm{ha}-0.074 \mathrm{mg} / \mathrm{kg}$, background + preparation $200 \mathrm{~kg} / \mathrm{ha}-0.041 \mathrm{mg} / \mathrm{kg}$, background + preparation $400 \mathrm{~kg} / \mathrm{ha}-0.064 \mathrm{mg} / \mathrm{kg}$;

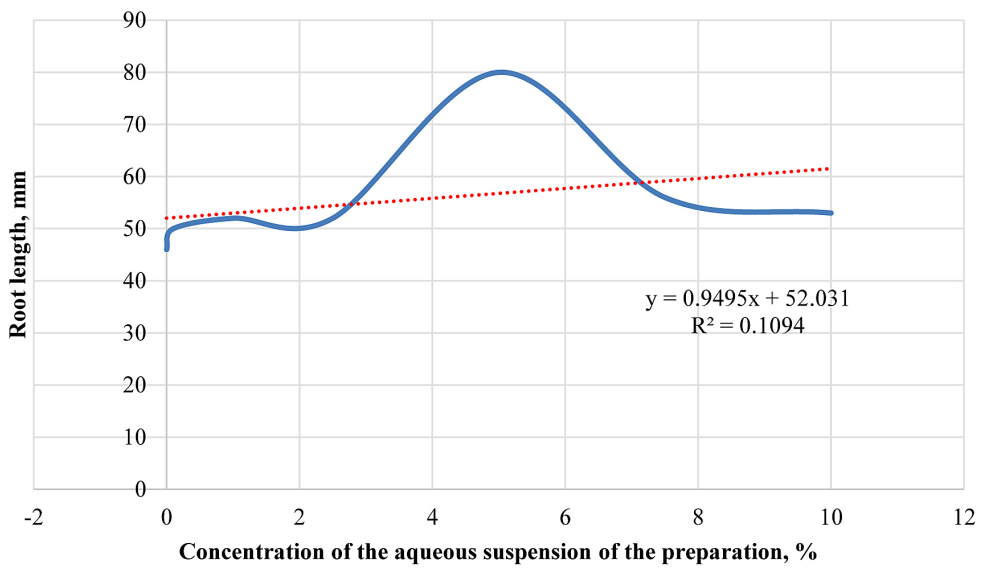

Figure 3. The effect of the multicomponent carbon-containing preparation concentration along the length of the roots of oil flax 


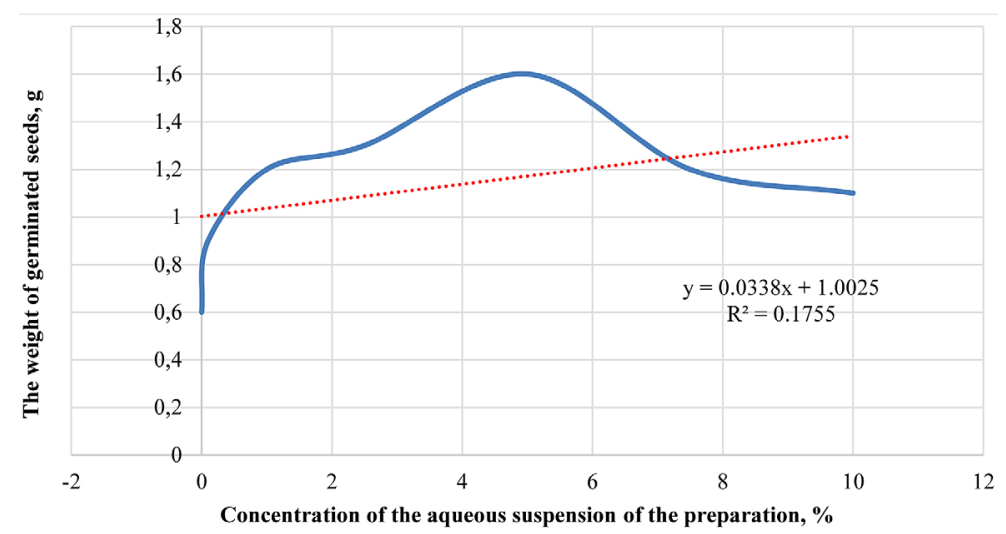

Figure 4. The effect of the multicomponent carbon-containing preparation concentration on the weight of germinated oil flax seeds

in the reference $-0.024 \mathrm{mg} / \mathrm{kg}$, and in other variants, no accumulation of copper was detected.

Accumulation of arsenic in the stems of the plants was detected in the reference $-0.054 \mathrm{mg} / \mathrm{kg}$ and background $+100 \mathrm{~kg} / \mathrm{ha}-0.037 \mathrm{mg} / \mathrm{kg}$; in other variants with fertilization, no arsenic was detected. In the stems and the seeds of oil flax, no cadmium and mercury were detected (Table 1).

\section{DISCUSSION}

From literature sources, it is known that various techniques are used for increasing the activity of seed germination. For instance, biologically active compounds are used for pre-sowing treatment of soybean seeds (lignohumate - a mixture of humic and fulvic acids, lexin - a mixture of

Table 1. The effect of the dosages of the preparation made from bottom ash and nanocarbon on the content of heavy metals in the soil, the stems, and the seeds of oil flax

\begin{tabular}{|c|c|c|c|c|c|c|c|c|}
\hline \multirow{2}{*}{ No. } & \multirow{2}{*}{ Variant } & \multirow{2}{*}{ Object } & \multicolumn{6}{|c|}{ Heavy metals, mg/kg } \\
\hline & & & $\mathrm{Pb}$ & $\mathrm{Cd}$ & $\mathrm{Zn}$ & $\mathrm{Cu}$ & As & $\mathrm{Hg}$ \\
\hline \multirow{3}{*}{1} & \multirow{3}{*}{$\begin{array}{l}\text { Reference without } \\
\text { fertilization }\end{array}$} & Soil & 0.52 & 0.000 & 0.000 & 0.024 & - & - \\
\hline & & Stems & 0.63 & 0.000 & & & 0.054 & 0.000 \\
\hline & & Seeds & 0.26 & 0.000 & & & 0.000 & 0.000 \\
\hline \multirow{3}{*}{2} & \multirow{3}{*}{$1 / 10 P_{10}-$ background } & Soil & 1.1 & 0.090 & 0.34 & 0.000 & - & - \\
\hline & & Stems & 0.46 & 0.000 & & & 0.000 & 0.000 \\
\hline & & Seeds & 0.21 & 0.000 & & & 0.000 & 0.000 \\
\hline \multirow{3}{*}{3} & \multirow{3}{*}{$\begin{array}{l}\text { Background + preparation } \\
100 \mathrm{~kg} / \mathrm{ha}\end{array}$} & Soil & 0.52 & 0.000 & 0.31 & 0.074 & - & - \\
\hline & & Stems & 0.5 & 0.000 & & & 0.037 & 0.000 \\
\hline & & Seeds & & & & & & \\
\hline \multirow{3}{*}{4} & \multirow{3}{*}{$\begin{array}{l}\text { Background + preparation } \\
200 \mathrm{~kg} / \mathrm{ha}\end{array}$} & Soil & 1.2 & 0.000 & 1.4 & 0.041 & - & - \\
\hline & & Stems & & & & & & \\
\hline & & Seeds & 0.3 & 0.000 & & & 0.000 & 0.000 \\
\hline \multirow{3}{*}{5} & \multirow{3}{*}{$\begin{array}{l}\text { Background + preparation } \\
300 \mathrm{~kg} / \mathrm{ha}\end{array}$} & Soil & 1.0 & 0.000 & 0.36 & 0.000 & - & - \\
\hline & & Stems & 0.32 & 0.000 & & & 0.000 & 0.000 \\
\hline & & Seeds & 0.37 & 0.000 & & & 0.000 & 0.000 \\
\hline \multirow{3}{*}{6} & \multirow{3}{*}{$\begin{array}{l}\text { Background + preparation } \\
400 \mathrm{~kg} / \mathrm{ha}\end{array}$} & Soil & 0.68 & 0.000 & 0.61 & 0.064 & - & - \\
\hline & & Stems & & & & & & \\
\hline & & Seeds & 0.19 & 0.000 & & & 0.000 & 0.000 \\
\hline \multirow{3}{*}{7} & \multirow{3}{*}{$\begin{array}{l}\text { Background + preparation } \\
500 \mathrm{~kg} / \mathrm{ha}\end{array}$} & Soil & 1.7 & 0.000 & 1.1 & 0.000 & - & - \\
\hline & & Stems & 0.65 & 0.000 & & & 0.000 & 0.000 \\
\hline & & Seeds & 0.27 & 0.000 & & & 0.000 & 0.000 \\
\hline & \multirow{3}{*}{ MPC } & Soil & 32 & $\mathrm{n} / \mathrm{a}$ & $\mathrm{n} / \mathrm{a}$ & $\mathrm{n} / \mathrm{a}$ & $\mathrm{n} / \mathrm{a}$ & $\mathrm{n} / \mathrm{a}$ \\
\hline & & Stems & $\mathrm{n} / \mathrm{a}$ & $\mathrm{n} / \mathrm{a}$ & $\mathrm{n} / \mathrm{a}$ & $\mathrm{n} / \mathrm{a}$ & $\mathrm{n} / \mathrm{a}$ & $\mathrm{n} / \mathrm{a}$ \\
\hline & & Seeds & 1.0 & 0.1 & & & 0.3 & 0.05 \\
\hline
\end{tabular}


humic and fulvic acids enriched with auxin, brassinosteroid - a synthetic analog to the natural 24 epibrassinolide), and the so-called "complete seed treatment" - a mixture of a saturated solution of sucrose, lexin, fungicide Maxim XL 035 FS, Syngenta and a pinolene-based adjuvant [Prochazka et al., 2016]; boiling of the seeds of Bauhinia rufescens in the water for 10 seconds [Asiedu et al., 2011]; magnet-treated water [ul Haq Z et al., 2016]; soaking the seeds of Bauhinia rufescens in hot water at $65{ }^{\circ} \mathrm{C}$ for 60 minutes [Opoku et al., 2018]; pre-sowing treatment of the seeds of Peela Raya (Brassica carianata L.) with microelements $\left(\mathrm{ZnSO}_{4}, \mathrm{MnSO}_{4}\right.$, and $\left.\mathrm{FeSO}_{4}\right)$ [Ullah et al., 2002]; treatment of the fig seeds with preparation GA3 [Oguzhan et al., 2012]; electromagnetic treatment of the seeds of Zea mays at the rate of $4 \mu \mathrm{t}$, with the three-minute exposure [Elizabeth et al., 2011]; the use of the magnetic field for the seeds of cotton for 30 minutes (MF-30) [Bilalis, et al., 2013]; the use of Gaucho $600 \mathrm{FS}$ at the dosage of $11 / 100 \mathrm{~kg}$ of soybean seeds [Ilieva and Vasileva, 2014]; treatment of the seeds of spring wheat of cultivar Esther with the ozone-and-air agent [Sabin et al., 2017]; treatment of the seeds of Lycopersicum esculentum with solutions of hydrogen peroxide and potassium permanganate [Baranova et al., 2014]; and treatment of the seed of oats by preparations Lamador, Planreez, Vial TrusT, ZHUSS [Zakharov et al., 2016].

The suggested preparation made of bottom ash and technical carbon is a readily available local inexpensive material. Its use in agriculture for the pre-sowing treatment of seeds and as a fertilizer is also environmentally significant in terms of disposal of production wastes.

Moreover, the studies have shown the ecological safety of the preparation made of bottom ash and technical carbon when used for fertilizing the soil under oil flax crops. The content of lead in the soil was 0.52 and $1.7 \mathrm{mg} / \mathrm{kg}$ (with the allowed rate equal to $32 \mathrm{mg} / \mathrm{kg}$ ); cadmium was not found, the content of zinc was $0.00-1.4 \mathrm{mg} / \mathrm{kg}$ (with the allowed rate not established), and the content of copper was $0.00-0.074 \mathrm{mg} / \mathrm{kg}$ (with the allowed rate not established).

Nguyen Xuan $\mathrm{Cu}$ [2015] states that soil and surface water contamination by heavy metals is a global environmental problem. There is quite a lot of information about the accumulation of heavy metals in the soil, in the water, and the plant products in Vietnam. The authors recommend using phosphate fertilizers and lime for reducing the content of copper, lead, and zinc in the soil and the plants.

In the experiment, the preparation made of bottom ash and technical carbon was used for the crops of oil flax on the background of phosphate fertilizers, which prevented the entry of heavy metals into the vegetable mass.

In Jordan, dozens of the most widely used fertilizers were studied for the level of heavy metals content in the soil and the leaves of lettuce. The results showed that the content of $\mathrm{Cd}$, $\mathrm{Ab}$, and $\mathrm{As}$ was within the acceptable limits [AlKhader, 2015].

Many-years studies by Wierzbowska et al. [2018] of sewage water, compost, and domestic wastes and manure showed that heavy metals were adsorbed stronger in the soil rich in organic matter, which positively correlated with the content of organic carbon.

The studied preparation contains carbon, which is converted in the soil into organic carbon, thereby limiting the entry of heavy metals into the plants of oil flax.

It should be noted that not only macroelements but also microelements are required for normal growth and development of the plants [Lebedev, 1988]. That is, heavy metals in the studied preparation serve as the nutrition medium for oil flax. However, as noted by DraszawkaBołzan and Cyraniak [2014] an excess of these elements may be phytotoxic.

The sources of heavy metal contamination, as indicated by Czarnecki and Düring [2015], may be natural ones, such as weathering, industry, fertilizers, and atmospheric precipitation. The authors studied the effect of long-term use of fertilizers on the soil properties, and the content of heavy metals in the soil. They found that after introducing mineral fertilizers for the last 14 years, the content of mobile forms of heavy metals in the soil has considerably increased [Czarnecki and Düring, 2015].

That is, pollution of soil and plants is possible even with the use of traditional fertilizers. This suggests the need for systematic environmental monitoring. The suggested preparation is no exception.

According to Honghua He et al. [2019], CFA is often used as a fertilizer to improve the physicochemical properties of the soil. However, CFA contains many rare earth elements (REE), which can pose an environmental hazard. Their results 
showed that adding CFA to the soil not always significantly increases the concentration in the plants [Honghua et al., 2019].

Olushola et al. [2019] believe that the phytotoxicity indicators include the germination of the seeds of millet (Panicum virgatum) and the morphometry of the plants. Experiments have shown that the effect of CFA increases seed germination depending on the concentration. $10 \%$ of CFA increased the growth of seedlings, while 15 and $20 \%$ of CFA reduced the growth of seedlings and caused leaves chlorosis [Olushola et al., 2019].

Adnan Shakeel et al. [2019] state that disposal of fly ash causes significant economic and ecological problems. Therefore, the authors studied the possibility of introducing fly ash into the soil for improving the growth and the yield of treacle mustard (Brassica juncea L. cv. Varuna), and studied the effect of various concentrations of fly ash $(0,10,20,30,40$, and $50 \mathrm{wt} \%$.) on the growth of the plants (the length, the fresh weight, and the dry weight of shoots and roots). It was found that the parameters had considerably increased from 10 to $30 \%$; the level of fly ash being at the maximum at $30 \%$. However, with higher levels of fly ash from 40 to $50 \%$, the growth parameters significantly reduced. Studying the data showed that the 30\% content of fly ash was ideal for the better growth of the treacle mustard [Shakeel et al., 2019].

In the experiment of the authors, the best concentration for oil flax was $5 \%$, while increasing the concentration to 7.5 and $10.0 \%$ decreased several physiological parameters.

Sung Chul Kim et al. [2017] note that adding coal ash to the acidic wastes reduces its acidity and provides essential nutrients for the plants. The treatment preparation was a mixture of coalmine wastes with coal ash. Adding coal ash increased the $\mathrm{pH}$ of the coal mine wastes and filtrate, and stimulated the growth of the plants. The use of coal ash also offers an environmentally compatible and cost-effective way of cleaning up coal mine wastes [Kim et al., 2017].

Fine slag has excellent properties, such as large surface area, a wide range of pore size, and high carbon content. This material can improve poor soils when added as a soil additive for alkaline sandy lands. The experiments with potted plants in a greenhouse showed that adding $20 \%$ of CGFS had considerably increased the germination of maize and wheat from zero to $100 \%$ [Dandan et al., 2019].
Thus, science and practice have developed a new approach to environmentally safe management of bottom ash for fertilizing the soil and for the pre-sowing treatment of the seeds of crops.

\section{CONCLUSION}

The suggested method involves pre-sowing treatment of the seeds of oil flax with the preparation made of bottom ash and technical carbon in the weight ratio of $2: 1$.

The use of $5 \%$ concentration increased the laboratory germination to $97 \%$ (in the reference $88 \%$ ), the length of mesocotyl to $80 \mathrm{~mm}$ and roots to $79 \mathrm{~mm}$ (in the reference, these values reached $55 \mathrm{~mm}$ and $46 \mathrm{~mm}$, respectively), and the weight of germinated oil flax seeds to $1.6 \mathrm{~g}$ (in the reference $-0.6 \mathrm{~g}$ ); as a consequence, the seeding rate was reduced, and the sprouts were even.

The pre-sowing treatment of oil flax seeds with the preparation made of bottom ash and technical carbon is agrobiologically effective for increasing the oil flax seeds germination vigor by $10.2 \%$, is environmentally attractive in terms of disposal of bottom ash and technical carbon, economically expedient given the use of inexpensive local secondary raw materials, and is readily available.

The results have shown that the introduction of the preparation made of bottom ash and technical carbon for pre-sowing treatment of seeds and for fertilizing black soils under the crops of flax is environmentally safe and does not contribute to excessive content of heavy metals; the content of lead in the soil was $0.52-1.7 \mathrm{mg} / \mathrm{kg}$ (the allowed rate was $32 \mathrm{mg} / \mathrm{kg}$ ); cadmium was not detected, the content of zinc was $0.00-1.4 \mathrm{mg} / \mathrm{kg}$ (with the allowed rate not established), and the content of copper was $0.00-0.074 \mathrm{mg} / \mathrm{kg}$ (with the allowed rate not established).

\section{Acknowledgments}

This research was made in the framework of project AR05131092 "Ecological and Agrochemical Assessment of Using preparations Made of Bottom Ash and Nanocarbon for Fertilizing Black Soils to Be Used for Agricultural Crops" under grant funding of the Science Committee of the Ministry of Education and Science of the Republic of Kazakhstan for 2018-2020. 


\section{REFERENCES}

1. AlKhader A. 2015. The Impact of Phosphorus Fertilizers on Heavy Metals Content of Soils and Vegetables Grown on Selected Farms in Jordan. Agrotechnol, 4, 137-142.

2. Asiedu J.B.K., Asare-Bediako E., Taah K.J., Buah J.N. 2011. Effect of Pre-Sowing Treatments on Seed Germination and Establishment of Bauhinia rufescens. International Journal of Agricultural Research, 6(7), 584-592.

3. Baranova T.V., Kalaev V.N., Voronin A.A. 2014. Ekologicheski bezopasnye stimulyatory rosta dlya predposevnoi obrabotki semyan [Environmentally safe growth stimulant for pre-sowing seed treatment]. News of the Baltic Federal University n.a. I. Kant. Series: Natural and Medical Sciences, 7, 96-102. (in Russian).

4. Draszawka-Bołzan B., Cyraniak E. 2014. Influence factors in soil-fertilizer accumulation of heavy metals in plants. World Scientific News, 3, 20-27.

5. Bilalis D.J., Katsenios N., Efthimiadou A., Karkanis A., Khah E.M., Mitsis T. 2013. Magnetic field presowing treatment as an organic friendly technique to promote plant growth and chemical elements accumulation in early stages of cotton. AJCS 7(1), 46-50.

6. Czarnecki S., Düring R.-A. 2015. Influence of long-term mineral fertilization on metal contents and properties of soil samples taken from different locations in Hesse, Germany. SOIL, 1, 23-33.

7. Dandan Zh., Shiding M., Bing X., Yinshan J., Cundi W. 2019. Effect of Coal Gasification Fine Slag on the Physicochemical Properties of Soil. Water, Air, \& Soil Pollution 230, 155.

8. GOST 12038-84 Interstate standard. Seeds of crops. Methods of determination of germination. Official edition as amended IUS No. 12, 2016. Standartinform, Moscow, 2011. (in Russian).

9. Honghua H., Chenbin F., Qi P., Miaomiao W., Jiyong Zh., Gao-Lin W. 2019. Bioaccumulation and translocation of rare earth elements in two forage legumes grown in soils treated with coal fly ash. Chemical Geology 528, 119284.

10. Ilieva A., Vasileva V. 2014. Effect of pre-sowing treatment of seeds with insecticides on parameters related to nodulation and nitrate reduction in soybean [Glycine max (L.) Merr.]. Journal of Central European Agriculture, 15(2), 23-32.

11. Isaac A.E, Hernandez A.C, Dominguez A., Cruz A.O. 2011. Efecto pre siembra del tratamiento electromagnetico sobre la germinacion de semillas y el crecimiento de plantulas de maiz (Zea mays L.). Agron. colomb., 29(2).

12. Kauricheva I.S. 1986. Praktikum po pochvovedeniyu [Soil Science Workshop]. 4th edition. Agropromizdat, Moscow. (in Russian).
13. Khamphe Ph., Li-Ming Sh., Pin-Jing H., Hua Zh. 2018. Phytotoxicity and groundwater impacts of leaching from thermal treatment residues in roadways. Journal of Environmental Sciences, 63, 58-67.

14. Kim S.Ch., Oh S.J., Oh S.M., Lee S.Ph., Yang J.E. 2017. In situ reclamation of a closed coal mine waste in Korea using coal ash. Biological Chemistry, 60(3), 265-272.

15. Lebedev S.I. 1988. Fiziologiya rastenii [Plant physiology]. Agropromizdat, Moscow. (in Russian).

16. Mtisi, M., Gwenzi W. 2019. Evaluation of the phytotoxicity of coal ash on lettuce (Lactuca sativa L.) germination, growth, and metal uptake. Ecotoxicology and Environmental Safety, 170, 750-762.

17. Nguyen X.C. 2015. Effect of Heavy Metals on Plant Growth and Ability to Use Fertilizing Substances to Reduce Heavy Metal Accumulation by Brassica Juncea L. Czern. Global Journal of Science Frontier Research: D Agriculture and Veterinary, 15(3), 35-40.

18. Oguzhan C., Kazim M. Aytekin P. 2012. Influences of pre-sowing treatments on the germination and emergence of fig seeds (Ficus carica L.). Acta Sci Agron., 34(3).

19. Olushola M.A., Ekundayo O.A., Dzantor, E.K. 2019. Arbuscular mycorrhizal fungi, and exogenous glutathione mitigate coal fly ash (CFA)-induced phytotoxicity in CFA-contaminated soil. Journal of Environmental Management, 237, 449-456.

20. Opoku J.A., Amissah J.N, Essilfie M.E., Norman J.C. 2018. Effect of Pre-Sowing Treatments on Seed Germination and Seedling Growth of Silver Butterfly Tree (Bauhinia rufescens). Curr Agri Res., 6(3), 344-354.

21. Prochazka P., Stranc P., Pazderu K., Stranc J. 2016. The influence of pre-sowing seed treatment by biologically active compounds on soybean seed quality and yield. Plant Soil Environ., 62(11), 497-501.

22. Sabin S.A., Tyshkevich E.V., Ershova T.S. 2017. Vliianie na urozhainost iarovoi pshenitcy predposevnoi obrabotki semian ozonovozdushnym agentom. [The effect of pre-sowing seed treatment by ozone-and-air agent on the yield of spring wheat]. Sovremennye naukoemkie tekhnologii. Regionalnoe prilozhenie, 1(49), 130-135. (in Russian).

23. Sarenova A.A. 2013. Patent na izobreteniya - meliorativnyi preparat dlya povysheniya plodorodiya pochv [Invention patent - an ameliorative preparation for improving soil fertility]. EN 2494137 C2. 2013 No. 27. (in Russian).

24. Shakeel A., Khan A.A., Gufran A. 2019. The potential of thermal power plant fly ash to promote the growth of Indian mustard (Brassica juncea) in agricultural soils. SN Applied Sciences, 1, 375.

25. Singh P.K., Tripathi P., Dwivedi S., Awasthi S., Shri 
M., Chakrabarty D., Tripathi R.D. 2016. Fly-ash augmented soil enhances heavy metal accumulation and phytotoxicity in rice (Oryza sativa L.); A concern for fly-ash amendments in the agriculture sector. Plant Growth Regulation, 78(1), 21-30.

26. Handbook of pesticides (insecticides) approved for the use on the territory of the Republic of Kazakhstan fully corresponds to the List of pesticides (insecticides) approved for the use on the territory of the Republic of Kazakhstan in 2013-2022 and amendments, No. 1, No. 2, No. 3, No. 4, and No. 5. May 12, 2015. Publisher: Industrial Site «Uspekh», Almaty (in Russian).

27. ul Haq Z., Iqbal M., Jamil Ya., Anwar H., Younis A, Arif M., Zeshan M.F., Hussain F. 2016. Magnetically treated water irrigation effect on turnip seed germination, seedling growth, and enzymatic activities. Information Processing in Agriculture, 3(2), 99-106.

28. Ullah M.A., Sarfraz M., Mehdi S. M., Sadiq M.,
Hassan G., Jamil M. 2002. Effect of Pre-sowing Seed Treatment of Raya With Micronutrients on Yield Parameters. Asian Journal of Plant Sciences, 1, 277-278.

29. Usmani Z., Kumar V., Gupta P., Gupta G., Rani R., Chandra A. 2019. Enhanced soil fertility, plant growth promotion and microbial enzymatic activities of vermicomposted fly ash. Scientific Reports, 9, 10455.

30. Wierzbowska J., Kovacik P., Sienkiewicz S., Krzebietke S., Bowszys T. 2018. Determination of heavy metals and their availability to plants in soil fertilized with different waste substances. Environ Monit Assess., 190(10), 567-579.

31. Zakharov V.K., Kolesnikov V.G., Fatykhov I.S. 2016. Predposevnaya obrabotka semyan i normy vyseva ovsa Yakov [Pre-sowing seed treatment and Jacob oats seeding rate]. News of the Izhevsk State Agricultural Academy: Agricultural science, 3(48), 3-10. (in Russian). 